\title{
La masonería española y la abolición de la esclavitud en las Antillas durante el Sexenio Democrático: movilización y dinámica socio-cultural ${ }^{*}$ \\ Spanish Freemasonry and the Abolition of Slavery in the Antilles During the Democratic Sexennium: Mobilization and Socio-Cultural Dynamics
}

\author{
Valeria Aguiar Bobet \\ ORCID iD: https://orcid.org/0000-0001-7343-5169 \\ Universitat Jaume I/Universidad de La Laguna, España \\ Manuel de Paz Sánchez \\ ORCID iD: https://orcid.org/0000-0002-9556-9157 \\ Universidad de La Laguna, España
}

El objetivo central de este ensayo es analizar la movilización social en la península ibérica contra la esclavitud en las Antillas españolas durante la etapa 1864-1874. Esta década se caracteriza, desde el punto de vista político e institucional, por dos hechos relevantes: la fundación de la Sociedad Abolicionista Española, y la revolución de septiembre de 1868 que dio lugar al Sexenio Democrático. Se analiza el papel que tuvo la masonería y algunos masones relevantes en la consecución de los objetivos abolicionistas, que contribuyeron al triunfo del ideal emancipador en Puerto Rico y a sentar las bases del proceso abolicionista en Cuba. Palabras clave: Masonería; Abolicionismo; Esclavitud; España; Antillas; Puerto Rico; Cuba.

The central objective of this essay is to analyze the social mobilization in the Iberian Peninsula against slavery in the Spanish Antilles during the period 1864-1874. This decade is characterized, from the political and institutional point of view, by two relevant events: the foundation of the Spanish Abolitionist Society, and the revolution of September 1868 that gave rise to the Democratic Sexennium. We analyze the role played by Freemasonry and some relevant Freemasons in the achievement of abolitionist objectives, which contributed to the triumph of the emancipatory ideal in Puerto Rico and to lay the foundations of the abolitionist process in Cuba.

KeYwords: Masonry; Abolitionism; Slavery; Spain; Antilles; Puerto Rico; Cuba.

Copyright: (C) 2021 CSIC. Este es un artículo de acceso abierto distribuido bajo los términos de la licencia de uso y distribución Creative Commons Reconocimiento 4.0 Internacional (CC BY 4.0).

* Trabajo realizado en el proyecto de investigación RTI2018-094305-B-I00 financiado por el Ministerio de Ciencia e Innovación, España. 


\section{Introducción}

En el marco del estudio de la protesta y de los movimientos sociales, la moderna historiografía ha insertado aquellos que describe como «activos», entre los que se sitúan los que algunos autores han definido, entre otros elementos constitutivos, por sus «metas precisas» como, por ejemplo, «la abolición de la esclavitud». ${ }^{1}$ Trataremos de adentrarnos, en este contexto, en los medios que se adoptaron, en el caso concreto de España (entre 1864 y el Sexenio Democrático) para alcanzar este tipo de meta colectiva. Uno de los elementos definitorios que salta a la vista, en relación con este tipo de análisis, es la frecuente utilización de exposiciones o petitorios que se presentan a las autoridades. Se intentará reflexionar igualmente sobre los objetivos que se conquistaron y que fueron un logro colectivo de ciudadanos de diferentes sensibilidades, ideologías y adscripciones políticas, cuya movilización en todos los ámbitos, incluido muy significativamente el cultural, contribuyó a la consecución de la abolición de la esclavitud, al menos, en Puerto Rico, a partir de la primavera de 1873, aparte de esbozar el camino para lo que unos años más tarde se tradujo en la deseada liberación de los esclavos cubanos.

Diversos intereses económicos y políticos, de mentalidades, así como el miedo al estallido de revueltas incontrolables por parte de los trabajadores forzados de color, junto a los intereses a corto plazo presionaron para relegar a un segundo plano los ideales de libertad, igualdad y fraternidad que, desde su nacimiento, habían caracterizado tanto a la orden del Gran Arquitecto del Universo (GADU) como a numerosos partidos y colectivos reformadores. Así, pues, aparte de contribuir a analizar el papel de la masonería española, sus principales integrantes y dirigentes en relación con la liberación de los esclavos antillanos, especialmente durante la época del Sexenio Democrático, nuestro objetivo es intentar aproximarnos a la influencia que pudieron tener los masones, en general, en las campañas abolicionistas del período, mediante la identificación de algunas decenas de iniciados que participaron en ellas y contribuyeron a promoverlas en diversos lugares de la España peninsular.

En las páginas que siguen trataremos de replantear algunos tópicos sobre los orígenes de la Sociedad Abolicionista Española (SAE), y, asimismo, de la presencia en su seno de miembros de la masonería más o

1 Burke, 2007, 135-140. Naranjo Orovio, 2014, 259-272. Piqueras, 2014, 145-171. 
menos destacados que, al mismo tiempo, desempeñaron importantes cargos institucionales y políticos. Se han utilizado para ello diversas fuentes hemerográficas que, junto a numerosos folletos, documentos impresos, algún manuscrito y bibliografía específica del periodo analizado, resultan indispensables para una mínima aproximación a los objetivos propuestos.

Ciertos hechos históricos de carácter híbrido por su composición y heterogeneidad jalonan los primeros tiempos de la historia fundacional del movimiento abolicionista español en la Península. En primer lugar, la creación de la Sociedad Abolicionista Española (SAE). En segundo término, las manifestaciones que tuvieron lugar en Madrid y en otros lugares de España, con la participación de determinados miembros de la orden, y, paralelamente, la dinamización cultural que se puso en funcionamiento, desde los primeros momentos, para agitar las conciencias a favor de la causa abolicionista, principalmente a través de la representación de dramas de contenido antiesclavista, aparte de otro tipo de convocatorias y actuaciones culturales. En todos estos hechos parecen tener un notable protagonismo varios miembros de la orden del GADU.

\section{Masones en los orígenes del movimiento abolicionista español}

Nos ocuparemos, en primer lugar, de la erección de la SAE y de las movilizaciones españolas a favor de la causa abolicionista, una de cuyas fuerzas motrices fue, precisamente, el ciudadano de origen puertorriqueño, Julio Vizcarrondo, avecindado en la capital de España a partir de 1863. Rafael María de Labra, que era el profeta antiesclavista español por antonomasia, ${ }^{2}$ aunque no aparece que fuera masón, ${ }^{3}$ se refirió a él en términos laudatorios en una de las entregas que dedicó a otro antiesclavista de renombre, don Fernando de Castro. «Debióse esta iniciativa», la de la fundación de la SAE, según apuntaba Labra, «al celo de un puertorriqueño que se había educado en los Estados Unidos, distinguiéndose en su propio país como periodista, partidario ardiente de las reformas políticas y activo miembro de la masonería. Me refiero a D. Julio Vizcarrondo». ${ }^{4}$

Labra mencionó, asimismo, al marqués de Albaida y a Nicolás Rivero como contrarios a la «esclavitud antillana» ya desde su etapa en las Cortes

2 Paniagua, 1990, 139-156. Rojas, 2013, 48-49.

3 Domingo Acebrón, 2004; 2006, 65.

4 Labra, 1888, 383. 
de 1855, aparte de señalar que, «en el programa democrático de la célebre Discusión», se había afirmado la «idea abolicionista», aunque se trataba, hasta entonces, de «esfuerzos individuales y aislados». Sería precisamente «hacia 1863» cuando aquella idea «reviste eficacia», es decir, a partir de la fundación de la SAE. ${ }^{5}$ Resulta curioso que Labra no siendo miembro de la masonería se refiriera al alto perfil masónico del fundador de la sociedad, el puertorriqueño Vizcarrondo. Pero existieron otros veteranos de la entidad que también pudieron haber formado parte del selecto club de los Hijos de la Viuda. Es el caso, por ejemplo, del citado marqués de Albaida, José María Orense de Milá de Aragón, diputado a Cortes en diversas convocatorias, quien también se había hecho cargo, el 2 de abril de 1865, de una de las vicepresidencias fundacionales de la entidad abolicionista. Entre otras responsabilidades llegó a ocupar más tarde la presidencia, para la que fue designado el 30 de noviembre de 1868, tras una etapa de decadencia, con lo que estuvo al frente, por tanto, del meeting del Circo Price del 5 de diciembre de $1868 .{ }^{6}$ Morayta y Alvarado Planas lo consideran miembro de la orden, ${ }^{7}$ pero no especifican ni la obediencia concreta ni el momento de su recepción. ${ }^{8}$

Sobre el demócrata sevillano, Nicolás María Rivero, que fue alcalde de Madrid, presidente del Congreso de los Diputados y ministro de la Gobernación durante los primeros años del Sexenio, Morayta parece integrarlo en las filas de la orden, ${ }^{9}$ mientras que Díaz y Pérez tiende a ubicarlo, más bien, entre los carbonarios,,$^{10}$ una sociedad secreta, la carbonería, que había surgido en Nápoles a principios del XIX y era de marcado carácter político. No parece que exista constancia segura de su condición masónica, ${ }^{11}$ pues Vicente de la Fuente no constituye una referencia fiable, ya que se basó en cierta información procedente de una carta cuya autoría ocultó en su momento el redactor del periódico madrileño La Época, donde se aludía, en efecto, a la «designación del Sr. Machado para gobernador» de Sevilla, nombramiento que había sido efectuado «por el Gran Oriente de la

5 Idem.

6 Ibidem, 386. Un meeting especial que, aparte de simbolizar el renacer de la SAE, el escenario elegido ofrecía un marco idóneo desde el punto de vista socio-político. Higueras, 2016, 82.

7 Morayta, 1915, 213: «Marqués de Albaida, presidente de las Constituyentes de 1873». Alvarado Planas, 2016, 173.

8 Valín, 1993, I: 518, lo sugiere.

9 Morayta, 1915, 217.

10 Díaz y Pérez, 1894, 478, 489.

11 Arias Castañón y Enríquez del Árbol, 1989, I: 49. 
comunión masónica, a que se dice que pertenece el Sr. Rivero». ${ }^{12}$ Antiesclavista convencido, Labra asegura por su parte que, desde su puesto en la Junta Superior Revolucionaria de la capital de España, apoyó el proceso abolicionista, mediante la declaración institucional del 15 de octubre de $1868,{ }^{13}$ que venía a recoger las aspiraciones de la citada Junta, para que se aplicara por el gobierno provisional la libertad a todos los nacidos de mujer esclava, a partir del 17 de septiembre de $1868 .^{14}$

El relato de Labra, con todo, yerra en la fecha de la fundación o primer ensayo fundacional de la futura SAE, ya que la sitúa como acabamos de ver en el año de 1863, en lugar del de 1864. Planteó también que las primeras gestiones de Vizcarrondo, que fue el principal motor de la iniciativa, estuvieron dirigidas a «solicitar el apoyo de los elementos ultramarinos» residentes en la capital de la monarquía, pero no tuvo éxito, pues «las gentes que habían crecido entre las preocupaciones antillanas y aquí vivían de los pasados errores, no podían creer que había llegado el tiempo de hacer otra cosa» que «dulcificar la situación del esclavo». En consecuencia, el puertorriqueño buscó el apoyo de otros círculos, en especial, el de «los economistas y el de los demócratas», aunque, matiza, «las cosas no resultaron del primer empuje». ${ }^{15}$

Al fin, el 7 de diciembre de 1864, se reunieron en la calle del Soldado, número 4, en casa del propio Vizcarrondo, algunas personalidades que encarrilaron el proceso fundacional. Labra menciona a varios de ellos, a saber, los dos hermanos Asquerino, ${ }^{16}$ los economistas Félix de Bona, Laureano Figuerola, Gabriel Rodríguez, Joaquín María Sanromá, Alonso de Beraza y Mariano Carreras y González. A ellos se sumaron el cubano Francisco Orgaz y «los señores Orihuela y Valentí». ${ }^{17}$ Subraya que «al pensamiento se habían adherido también los cubanos» Andrés de Arango, Calixto Bernal, Federico de Arango, Tristán Medina y Antonio Angulo de Heredia, y,

12 La Época, Madrid, 7 de marzo de 1870, 2. La Esperanza, Madrid, 8 de marzo de 1870, 3.

13 Labra, 1888, 387-388.

14 Serván, 2017, 99-101.

15 Labra, 1888, 383-384. La Sociedad Libre de Economía Política de Madrid incluyó, entre los puntos a tratar en la reunión del 14 de noviembre de 1864, el tema de la esclavitud «bajo el punto de vista económico, y examen de los medios que deben emplearse para su abolición, en el caso de que esta sea conveniente», El Contemporáneo, Madrid, 13 de noviembre de 1864, 3.

16 Eduardo y Eusebio Asquerino García, escritores y periodistas. López-Ocón Cabrera, 1990, 205-246. Eduardo, que también fue diputado y diplomático, fundador y propietario de La América de Madrid, figura, según Morayta $(1915,215)$, entre los representantes de la nación que «vieron la luz».

17 Labra, 1888, 384. Orihuela era el canario Andrés Avelino de Orihuela, autor de la novela antiesclavista El Sol de Jesús del Monte, Hernández Paz, 2007. 
asimismo, «los peninsulares» Fermín Caballero ${ }^{18}$ y Segismundo Moret y Prendergast, ${ }^{19}$ de cuya vinculación y prestigio en el seno de la masonería española no existen dudas. Concluye Labra que de aquella reunión saldrían los acuerdos que permitieron constituir definitivamente la SAE, acto que se llevó a cabo en la Academia de Jurisprudencia el 2 de abril de $1865 .^{20}$

Diversos autores coinciden, en términos generales, con lo más sustancial del relato de Labra. ${ }^{21}$ Pero, la percepción de los hechos no fue unánime para sus contemporáneos. En 1864, las perspectivas no parecían tan halagüeñas como parece observarse en su descripción. En la Revista Hispano-Americana, que Labra no desconocía en absoluto, ${ }^{22}$ se publicó a finales de 1864 una crónica bajo el seudónimo Agüeinaba, que bien podía disimular la verdadera identidad del autor, tal vez el propio Julio Vizcarrondo, quien ejercía de copropietario y secretario de la revista, mientras que Antonio Angulo Heredia figuraba a cargo de la dirección. ${ }^{23}$ A mediados de 1865 se fundó El Abolicionista, órgano de la SAE, que como afirma Castellano se publicaba con bastante irregularidad. Tuvo altibajos, en efecto, pero volvió a imprimirse a partir de $1870 .^{24}$

\section{Contratiempos iniciales}

A los primeros llamamientos para la constitución de una entidad partidaria de la abolición por la vía rápida habían acudido personas de diferente adscripción político-ideológica. El autor de la crónica no dudó en afirmar que se trató de una primera tentativa que estuvo condenada al fracaso, dada la presencia en su seno de numerosos elementos conservadores y algunos convencidos esclavistas. Estas primeras reuniones que se celebraron en casa de Fernando Corradi no llevaron a ningún sitio. Asistieron

18 Uno de los vicepresidentes fundacionales, vinculado también a la orden por Morayta, 1915, $155,169$.

19 Morayta, 1915, 213, 217 lo sitúa entre las glorias masónicas del Sexenio. Estuvo al frente de varios ministerios y ostentó la jefatura del Gobierno de España. Ferrer Benimeli, 2007, 167-192. Álvarez Lázaro, 2006, 156. Galván Rodríguez, 2014, 115, 129-130, 208-209.

20 Labra, 1888, 384. Rodríguez Pérez y Vizcarrondo Sabater, 2008, 306-307.

21 Castellano, 1965, 9-13. Arroyo Jiménez, 1982, 128-129; 1990. Ayala, 1991, 178. Pinto Tortosa, 2018, 133

22 Rodríguez Pérez y Vizcarrondo Sabater, 2008, 305.

23 Colaboraron en ella, entre otros varios que utilizaban las iniciales de sus nombres y también estuvieron vinculados a la SAE, Calixto Bernal, Félix Bona, C. de Arozarena o J. M. Escoriaza.

24 Castellano, 1965, 21. Pérez-Prendes, 1986, 215-240. 
a ellas, entre otros, Jacobo de la Pezuela, el magistrado Mariano Nogués o F. Merino Ballesteros. La comisión, decía el cronista, «dio principio a sus tareas tropezando con el natural entorpecimiento de la divergencia de ideas entre sus miembros», y, desde la primera reunión, «fue fácil descubrir que habían concurrido a ella personas que profesaban ideas diametralmente opuestas». La presidió el senador Andrés Arango y, entre sus vocales, aparte de Corradi, Pezuela, Nogués y Merino Ballesteros, estaban también Julio Vizcarrondo, el presbítero Tristán Medina y Félix de Bona. La secretaría recayó en Andrés Avelino de Orihuela, que había viajado desde París a Madrid, en compañía del secretario de la asociación abolicionista de Londres, Sammerson. Así, pues, como destacaron algunos periódicos cuyo texto se reprodujo con exactitud en el relato del que venimos hablando, «es verdad que esa reunión se proyectó para tratar el asunto referido, pero es evidente que esa junta, más bien que de abolicionistas, fue de esclavistas». En tal sentido se apuntó que el señor Pezuela «combatió hasta con el sarcasmo la idea de la abolición» y que, en resumen, el propio «nombramiento de la comisión fue arbitrario; con decir que hay esclavistas en la comisión basta». ${ }^{25}$

Algunos de los elementos más tibios del incipiente movimiento abolicionista español se integraron poco después en las filas de la SAE, pero otros abandonaron desde sus inicios cualquier intentona reformista, desde la Metrópoli, en el complejo entramado socio-económico de las Antillas. Los más conservadores optaron por dar a aquel embrión de entidad el nombre de Sociedad de conferencias ${ }^{26}$ y, como afirma también el autor de la crónica, «la llamada Sociedad abolicionista acababa de morir a manos de sus propios padres». En la prensa se publicaron algunos sueltos que negaban el carácter abolicionista de la frustrada entidad, reconocían no obstante que la reunión inicial fue promovida por los partidarios de la abolición y aclaraban que la comisión tenía como objetivo debatir acerca de los medios más adecuados para hacer posible, «gradual y sucesivamente la emancipación de los esclavos en nuestras posesiones ultramarinas». Finalmente, la comisión optó por suspender las reuniones y por «limitarse a exponer al Gobierno el resultado de sus trabajos $»^{27}$. Concluía, sin embargo, el autor de la crónica

25 Agüeinaba, «La opinión pública y las reformas liberales en las Antillas españolas», Revista Hispano-Americana, Madrid, 1864, 197-202. Entre los fundadores y vocales, según recogió La Época, 17 de octubre de 1864, 3, estaba también Luis María Pastor. Medina declinó finalmente su nombramiento.

26 Varios periódicos la denominaron «Sociedad Cubana Abolicionista», como, por ejemplo, El Contemporáneo, 13 de noviembre de 1864, 2.

27 El comunicado se publicó en El Contemporáneo, 18 de noviembre de 1864, 2, entre otros. 
que las citaciones habían sido hechas claramente para la creación de una Sociedad abolicionista española, y que si no se acudía al llamamiento de la comisión era porque entre sus miembros no existía la «homogeneidad necesaria». Por todo ello, subrayaba Agüeinaba, se hacía necesario potenciar la creación de una entidad para buscar soluciones a la cuestión de la esclavitud. «Nuestros hermanos de Cuba y Puerto Rico no podrán menos de recibir satisfechos esta importante noticia. Las exigencias de la civilización, por un lado, la presión que ejercen los acontecimientos de la unión americana, por otro, hacen necesario el estudio de ese grave problema social». ${ }^{28}$

Es importante tener en cuenta en relación con lo anterior que a partir del triunfo de la revolución de 1868, momento en que la SAE al decir de Labra «hubo de resucitar en el otoño» de aquel año, ${ }^{29}$ que al mismo tiempo se erigieron «de acuerdo con la de Madrid» sociedades abolicionistas por toda España. En la junta general de la propia SAE madrileña, celebrada el 19 de noviembre de 1868, se informó de la constitución de entidades en Barcelona, Zaragoza, Valencia, Málaga, Sevilla, Alicante, Cádiz, Jaén, Oviedo, Tarragona, Cáceres, Cartagena, Guadalajara, Almería, Santander, Cuenca, Soria, Alhama de Aragón, Villalba de Extremadura «y otras muchas poblaciones». ${ }^{30}$ Ahora bien, antes de la definitiva consolidación de la SAE, también se dieron algunos episodios de indudable importancia socio-cultural en relación con los orígenes del movimiento abolicionista español.

\section{Aspectos socio-culturales: los masones y el teatro antiesclavista}

El estreno a finales de 1864, en el Teatro Novedades de Madrid, del drama en cinco actos y seis cuadros intitulado Cora o la esclavitud ${ }^{31}$ obra del francés Paul-Jules Barbier o, simplemente, Jules Barbier (1825-1901), constituye un acontecimiento masónico-cultural y abolicionista en sí mismo, ya que la inicial prohibición del estreno por el censor de teatros generó cierta campaña en la prensa que, si bien no garantizó el éxito de la obra, sirvió cuando menos para que podamos acercarnos a las emociones, los sentimientos y las ideas antiesclavistas que rodeaban a un sector de los dirigentes intelectuales y políticas de la época, principalmente de los más

28 Ibidem.

29 Labra, 1888, 386.

30 La Discusión, 21 de noviembre de 1868, 2.

31 Sabourin, 2008. Cooper, 2002, 360-378. 
próximos al republicanismo y al progresismo de estos tiempos previos a la revolución de 1868 . Y, más concretamente, a los de un personaje que andando el tiempo se convirtió en una de las figuras cimeras de la masonería española de finales del siglo XIX y principios del XX, el historiador, periodista y político don Miguel Morayta Sagrario. ${ }^{32}$

En efecto, el censor de teatros resolvió el 19 de noviembre de 1864, que examinado el drama referido «creo que debe prohibirse, por ser contrario a la Ley de Indias». ${ }^{33}$ Tres días después, el 22 de noviembre, Morayta elevó una súplica al ministro de la Gobernación, al objeto de que se reconsiderase la resolución negativa del censor. A tal fin, el futuro gran maestre argumentó razones económicas y éticas. Entre las primeras destacaban, sobre todo, los perjuicios que se le iban a originar a la empresa del Novedades y, asimismo, al propio autor de la traducción, ya que se había planificado su estreno para las «próximas Pascuas». Y, en segundo lugar, «porque el objeto del drama [...], es atacar la esclavitud, institución altamente antisocial y anticristiana». En tal sentido planteaba que no era posible que «V. E. se oponga a que, en el teatro como en el periódico y en la cátedra se defiendan los principios de moralidad y de justicia sobre que descansan las sociedades modernas». ${ }^{34}$ Por todo ello, pedía que se designase un «competente tribunal» para que reevaluase la obra y se pudiera llevar a escena.

La comisión estuvo integrada por cuatro dramaturgos y escritores, ya que la presidencia, que se ofreció a un título de Castilla, parece que no fue aceptada finalmente. Entre los comisionados se contó con Luis [Martínez] de Eguílaz, Luis Mariano de Larra (hijo de Mariano José de Larra), Eugenio Rubí y Fernando Martínez Pedrosa. ${ }^{35}$ Tras un examen escrupuloso, según manifestaron, resolvieron por unanimidad que las circunstancias especiales «en que se encuentran nuestras Antillas en la cuestión de la esclavitud, han dado indudablemente justo y fundado motivo al dictamen del señor censor de Teatros», pero, en realidad, se trataba de unas circunstancias concretas que no existían «en el resto de la Monarquía», por lo que no encontraban

32 Álvarez Lázaro, 2006, 362-366; 2012, 133-134, 140-142. Se había iniciado en julio de 1863 y, en 1871, estaba en posesión del último grado del REAA. En 1889 contribuyó decisivamente a la fundación del GOE, obediencia de la que actuó como dirigente hasta su muerte en 1917. Ferrer Benimeli, 2007, 152-155, 378. Alvarado Planas, 2016, 239, 242.

33 Miguel Morayta, «Cora o la esclavitud: drama en cinco actos y seis cuadros», c. 1864, Biblioteca Nacional de España, Madrid (BNE), Ms. 14273/3, II. El expediente incluye la documentación de la censura, que no está ordenada en sentido cronológico. Barbier, 1861.

34 Miguel Morayta, «Cora o la esclavitud: drama en cinco actos y seis cuadros», c. 1864, BNE, Ms. 14273/3, XIV-XV.

35 Ibidem, XVI-XVII. Se reunieron en Madrid el 3 de diciembre de 1864. 
inconveniente en que la representación se autorizase «no tan solo en los teatros de la Península, sino también en los de las colonias en que no exista la esclavitud». ${ }^{36} \mathrm{La}$ decisión fue un tanto salomónica y, en cierto modo, cínica. Los dramaturgos responsables del dictamen es probable que no quisieran malquistarse con el censor de teatros por obvias razones de índole profesional y, al mismo tiempo, no impedían la representación del drama en aquellos lugares del reino donde no existiese la esclavitud, una forma podría decirse de sumarse a la incipiente campaña a favor de la abolición.

El tribunal planteó también dos ligeras modificaciones en el texto de la traducción, al objeto, según explicaron sus integrantes, de «evitar las interpretaciones a que pudieran dar lugar ciertas ideas que, aunque nada tienen de perniciosas, están expresadas de un modo equívoco». ${ }^{37}$ Estas modificaciones, más que a la traducción realizada por Morayta, se referían al propio texto de Barbier. El drama se desarrollaba en Luisiana. La censura de la escena primera trató de escatimar el sentido, en cierto modo erótico, del diálogo entre dos de los protagonistas varones (los jugadores de whist Curtis y Georges), quienes comentaban los atractivos de una joven de «esbelto y gracioso talle», de la que Georges describe «extasiado su hermosa cabellera, su mirada dulce y velada, su nariz ardientemente abierta y, aún más, la indefinible gracia de todos sus movimientos». ${ }^{38}$

El segundo cambio sugerido parece tener relación, más bien, con el rango social dominante en esta época. Gerard le dice a Toby: «iToby!... ¡Me seguirás a Francia!... ¡ De ahora en adelante eres libre!... ¡Allí serás mi igual!... ¡Que esta reparación tardía te haga olvidar el pasado! (Se inclina ante Toby). ¡Perdona a tu viejo maestro que se humilla delante de ti!». ${ }^{39}$ Actitud que, por supuesto, rechaza de plano el antiguo esclavo por razones que tienen que ver con su posición de clase $\mathrm{y}$, sobre todo, con la dinámica propia del drama: «Oh!... Que faites-vous?... Non!... Je n'en suis pas digne!... Si vous saviez!...».

En consecuencia, el 9 de diciembre de 1864, la Sección de Orden Público de la Subsecretaría de Gobernación comunicó al gobernador civil que,

36 Ibidem, XXII.

37 Ibidem, XXIIv-XXIII.

38 Ibidem, 4. Barbier, 1861, 1: «Vous avez deviné juste; je ne puis me lasser d'admirer ces cheveux abondants, ce regard doux et voilé, ces narines ardemment ouvertes, et plus encore cette grâce indéfinissable qu'elle a dans tous ses mouvements. La connaissez-vous?».

39 Ibidem, 174. Barbier, 1861, 114: «Toby!... tu me suivras en France!... Dès maintenant tu es libre!... Là-bas tu seras mon égal!... Puisse cette tardive réparation te faire oublier le passé! (S'inclinant devant Toby). Pardonne a ton ancien maitre qui s'humilie devant toi!». 
teniendo en cuenta los criterios expresados por el jurado, se había accedido a permitir la representación de la obra en los teatros de la Península y colonias donde no estuviese vigente la esclavitud, al tiempo que se admitían las ligeras modificaciones del libreto propuestas por los comisionados..$^{40}$

Morayta, mientras tanto, no se había quedado de brazos cruzados. El 22 de noviembre, el mismo día que elevó su instancia al Ministerio, se dirigió a la prensa madrileña en defensa de su causa. El Contemporáneo le publicó su comunicado dos días después. En él ponía de relieve en primer lugar que, cuando la obra fue traducida al portugués, el escritor Antonio da Silva Tulio, que era el censor de los teatros lusos, había acogido su difusión en términos laudatorios:

Esta pieza pertenece al género de los Dramas sociales, así llamados en Francia, y tiene por argumento la gran cuestión de la esclavitud, que hoy trae en cruenta guerra a los Estados del Norte contra los del Sur, en la América inglesa.

En uno de estos Estados, en la Luisiana, pasan todos los actos menos el primero.

El drama está escrito con el pensamiento de defender la santa causa de la libertad y emancipación de los esclavos. La doctrina, los hechos, los lances y el desenlace, todo concurre a probar, muy verosímil y lógicamente, la tesis que el autor pone en acción. Se ve, pues, que tal pieza es muy digna por el asunto y por su mérito, de representarse en el teatro normal; y desgracia sería que no lograse la misma suerte que alcanzó en París. ${ }^{41}$

Planteaba también Morayta que no había ninguna razón para prohibir la obra, dado que en España se podía escribir libremente contra la esclavitud, ya que circulaban «con aplauso las traducciones de la Cabaña de Tomás $^{42}$ y tantas obras semejantes, cierto estoy de que la disposición del censor ha de ser corregida por la autoridad a quien hoy mismo acudo». Por todo ello, pedía el apoyo del periódico y de la prensa en general para que la representación, prevista para Nochebuena, se pudiese realizar sin causar graves perjuicios al Novedades. ${ }^{43}$

Después del estreno, la crítica fue bastante unánime a la hora de denostar su calidad. El crítico del diario «democrático» La Discusión, puso de

40 Ibidem, XXIV.

41 «Comunicado», El Contemporáneo, 24 de noviembre de 1864, 3-4.

42 Una de las primeras traducciones de La Cabaña del tío Tom, de Harriet Beecher Stowe, fue obra del tinerfeño José A. Pérez Carrión, cuya publicación por entregas, en el periódico $L a F e$ de Santa Cruz de Tenerife, comenzó el 4 de enero de 1857. Pérez Carrión consideraba que esta obra era «el golpe más profundo que se ha dado a esta institución impía, la esclavitud», precisamente de «la mano de una mujer», Hernández González, 2004, 15.

43 «Comunicado», El Contemporáneo, 24 de noviembre de 1864, 3-4. Se hicieron eco de la censura de la obra otros periódicos como La Nación, Madrid, 27 de noviembre de 1864, 1. 
relieve que «los tres primeros actos pasaron desapercibidos para el público. Los otros tres fueron más afortunados, siendo aplaudidos, y llamado el traductor a la escena, que no se presentó». ${ }^{44}$ A su vez, en La Iberia que a la sazón figuraba bajo la dirección de Práxedes Mateo Sagasta, quien pudo ser iniciado «a finales de la monarquía isabelina», ${ }^{45}$ se indicó, por ejemplo, que la obra entrañaba «un pensamiento social de gran trascendencia, y muy en consonancia con el espíritu de nuestro siglo, cual es el de querer borrar de las costumbres de un pueblo que blasona de libre, las odiosas distinciones de raza. Pero ni por su estructura, ni por la novedad de las situaciones, ni por lo saliente de los caracteres consigue el drama interesar». ${ }^{46}$

El comentarista del «diario progresista» La Nación navegó entre la ironía y el sarcasmo. «En Novedades», escribió el 4 de enero de 1865, «nace, muere y resucita el drama Cora o la esclavitud, más famoso por lo que ha dado que hablar a la prensa, que por sus propios merecimientos. Esta obra es, en efecto, lánguida, confusa y poco dramática», y concluyó su suelto con esta irónica frase: «La esclavitud, contra la opinión del dramaturgo portugués, es necesaria en donde haya actores que recen su papel como el padre nuestro». El Pensamiento Español, neocatólico y tradicionalista, se hacía eco unos meses más tarde, el 22 de abril de 1865, de que, a pesar de que se había prohibido en su momento el drama «Cora o la esclavitud, que tenía por objeto presentar los desastrosos efectos de dicha esclavitud en Norte-América, país clásico de la verdadera libertad, como le llaman sus admiradores», se había permitido la puesta en escena, en el mismo teatro Novedades y sin mayores contratiempos, de otra obra «donde aparece un sacerdote llamado el padre Claudio, y le presenta el autor como cómplice en una larga serie de crímenes con cierto gobernador de Italia». Por ello, se preguntaba el periódico: «¿A dónde hemos llegado? ¿Dónde está el saludable rigor de la censura de teatros?». La situación general de España no tardaría en experimentar cambios importantes.

\section{Salir a la luz: masones en las movilizaciones contra la esclavitud}

Entre las movilizaciones abolicionistas que tuvieron lugar en España, en pleno Sexenio Democrático, ocupa un lugar destacado la que se celebró

44 La Discusión, 27 de diciembre de 1864, 3.

45 Álvarez Lázaro, 2006, 360.

46 La Iberia, Madrid, 1 de enero de 1865, 3. 
en Madrid el 12 de enero de 1873. A ella se alude por diversos autores, ${ }^{47}$ aunque la participación en esta marcha de numerosos miembros de la masonería no ha sido destacada suficientemente. Merece la pena tratar de analizar su impacto y su relevancia socio-política en relación con la configuración de las luchas abolicionistas españolas, sus implicaciones ideológicas y específicamente masónicas.

Aparte del futuro y muy representativo gran maestre del Gran Oriente Español (GOE), es decir, del propio historiador Miguel Morayta Sagrario, ${ }^{48}$ al que acabamos de referirnos, tuvieron puestos de vanguardia en la marcha de Madrid, según La Correspondencia de España ${ }^{49}$ otros destacados personajes de la época, cuya vinculación con la masonería ofrece, cuando menos, indicios dignos de crédito. Es el caso por ejemplo de José Cristóbal Sorní, vocal de la Junta Revolucionaria de Madrid de la Septembrina y diputado en Cortes, que no tardaría en hacerse cargo, poco después de la citada manifestación, de la cartera de Ultramar, justamente entre el 24 de febrero y el 28 de junio de ese año. A Sorní le cupo el honor de que, gracias a sus gestiones, la Asamblea Nacional aprobara, antes de disolverse, la ley de abolición de la esclavitud en Puerto Rico, el 22 de marzo de 1873. Morayta, en cuyo periódico, La República Ibérica, había colaborado Sorní entre 1869 y 1871 , le sitúa entre los ministros que «vieron la luz». ${ }^{50} \mathrm{Al}$ final de la manifestación fue uno de los personajes que dirigió unas breves palabras a los asistentes.

El republicano Díaz Pérez, citado también en la nota de referencia, no es otro que Nicolás Díaz y Pérez, Viriato, ${ }^{51}$ un antiesclavista extremeño que tuvo una larga y fructífera trayectoria en el seno de la orden, en la que alcanzó el máximo grado del Rito Escocés Antiguo y Aceptado (REAA). Escribió, justamente, el tratado La Francmasonería española. Ensayo histórico-crítico de la Orden de los Francmasones en España, desde su origen hasta nuestros días, Madrid, Ricardo Fe, 1894, un texto voluntarioso, aunque propagandístico, algo pretencioso y con algunas deficiencias. Durante más de una década ostentó la veneratura de Comuneros de Castilla, ${ }^{52}$ logia

47 Ferris, 2008, 204. López-Ocón Cabrera, 1990, 215-216. Piqueras, 1992, 494.

48 Álvarez Lázaro, 2006, 362-366.

49 La Correspondencia de España, Madrid, 13 de enero de 1873, 3.

50 Morayta, 1915, 213. Díaz y Pérez, 1894, 489, en este último frente a la pena de muerte.

51 Díaz y Pérez, 1894, 614. Poyán Rasilla, 1987. Álvarez Lázaro, 1997, 186; 2006, 182. Lacalzada, 2008.

52 Randouyer, 1990. 
que también se destacó por sus luchas a favor de la supresión del Patronato en Cuba.

También estuvo al frente de la marcha madrileña del 12 de enero de 1873, el almeriense Ricardo López Vázquez, quien formó parte de las Cortes de la Primera República como diputado federal y, según Morayta, ostentó asimismo la secretaría de la Presidencia del Consejo. Era miembro del equipo que dirigía la SAE el 22 de septiembre de 1872, y, desde luego, está comprobado que perteneció a la masonería. ${ }^{53}$

Quintero, a no dudarlo, es Francisco Díaz Quintero. Masón famoso y, según Nicolás Estévanez, honrado y odiado por los voluntarios cubanos. Diputado durante todo el Sexenio democrático, rechazó la cartera ministerial que le propuso Francisco Pi y Margall, y fue amigo personal del héroe nacional cubano, José Martí. Mencionan su notable vinculación masónica Morayta, Díaz y Pérez o Caballero de Puga. El segundo lo situó, en ciertos momentos, como simpatizante carbonario más que como masón, pero también destacó sus conferencias de propaganda masónica y el hecho de que ocupara la veneratura de la logia Fraternidad de la capital de España, un taller del Grande Oriente Lusitano Unido (GOLU). Perteneció, asimismo, a la junta directiva de la SAE. ${ }^{54}$

Nicolás Salmerón no parece que llegara a iniciarse en la orden del GADU, ${ }^{55}$ a pesar de lo indicado por algunos autores antimasónicos. ${ }^{56} \mathrm{Mo}$ rayta dice que «simpatizaba», pero que «no le agradaba su secreto ni sus ritos». ${ }^{57}$ Integró la directiva de la SAE en diferentes momentos y se dirigió también al público al concluir la manifestación abolicionista de Madrid del 12 de enero de 1873. Tampoco su hermano Francisco Salmerón es seguro que reforzase las columnas de algún taller masónico, según se ha debatido con cierta frecuencia, ya que no se han hallado rastros documentales fehacientes. Diputado del Sexenio, vicepresidente del Congreso de los Diputados (1872), presidente de la Asamblea Nacional (1873), fue también ministro de Ultramar (1873), aunque de escasa duración, como solía ser frecuente en estos años. Morayta, que formó parte con él y con su hermano

53 Morayta, 1915, 215. Martínez López, 2010, 34. Cruz Artacho, 2016, 16.

54 Estévanez, 1975. Caballero de Puga, 1883, 22. Díaz y Pérez, 1894, 477, 492, 620. Morayta, 1915, 212, 213. Álvarez Lázaro, 1987, I: 31; 2012, 146. Paz Sánchez, 2008, 100, 102-107.

55 Ferrer Benimeli, 2010.

56 Polo, 1899, 27-28.

57 Morayta, 1915, 212-213. 
Emilio de la junta directiva de la SAE, por ejemplo, a principios de $1871,^{58}$ afirma que perteneció a la masonería, pero diferentes autores concuerdan en que no es una fuente definitiva. ${ }^{59}$ Sabemos con certeza, eso sí, que estuvo en primera fila, lo mismo que su hermano y que otros relevantes hombres públicos, en la manifestación abolicionista del 12 de enero de 1873. Por el contrario, sí parece que perteneció a la orden otro de estos famosos republicanos y abolicionistas, Luis Blanc Navarro, ${ }^{60}$ al que nos referiremos más adelante, en relación con un drama antiesclavista, Romper cadenas, que suscitó cierto interés entre un público especialmente sensibilizado con el problema.

También formaron parte de la comitiva presidencial de la manifestación madrileña del 12 de enero de 1873, según se informó ${ }^{61}$ otros personajes relevantes en relación con la SAE y con la orden del GADU, entre ellos, Manuel de Llano y Persi, Juan Bravo, y el general Lagunero. El primero llegó a ocupar, en masonería, los cargos de gran maestre adjunto del GODE y de gran teniente comendador del Supremo Consejo del Grado 33 (18721873), en diferentes momentos. Diputado en las Cortes del Sexenio, se le designó segundo secretario de las Constituyentes y también ocupó, entre otros puestos relevantes, el de consejero de Estado. ${ }^{62}$ Por su lado, también fue masón el mariscal de campo José Lagunero y Guijarro, diputado a Cortes en 1872 por Valladolid. Morayta le consigna entre los diputados del Sexenio que habían pertenecido a la masonería, ${ }^{63}$ lo que también parece ajustarse a la realidad. ${ }^{64}$

Cuando la manifestación, que se hizo acompañar de cuatro bandas de música ${ }^{65}$ y de grupos de personas con cartelones alusivos, pasaba por delante de las casas de algunos elementos opuestos a la abolición o partidarios, más bien, de un proceso legal más lento de cara a la emancipación definitiva, los músicos hacían un alto y entonaban el famoso Trágala, entre el regocijo de los paseantes. En «la manifestación negrófila del domingo», apuntaba un editorial del periódico conservador El Pensamiento Español,

58 La América, Madrid, XV:4, 26 de febrero de 1871, 6.

59 Ruiz Sánchez, 2010.

60 Morayta, 1915, 213. Díaz y Pérez, 1894, 497. Randouyer, 1985, 60.

61 Diario Oficial de Avisos de Madrid (DOAM), Madrid, 14 de enero de 1873, 4.

62 Díaz y Pérez, 1894, 623. Polo, 1899, 51. Morayta, 1915, 214. Randouyer, 1985, 60. Longobardo, 2004. Ferrer Benimeli, 2010, I: 12. Álvarez Lázaro, 2012, 136-137, 139, 146.

63 Morayta, 1915, 213. Ferrer Benimeli, 2010, I: 19-20. Ruiz Sánchez, 2010, I: 32-34, 37.

64 Longobardo, 2004, I: 855. García-Municio de Lucas, 2017, 348-349.

65 Cinco bandas, según el DOAM, 14 de enero de 1873, 4. 
una de sus víctimas había sido el señor Sagasta, justo cuando la marcha enfilaba frente a su casa en la calle de Alcalá. ${ }^{66}$ Otro de los «homenajeados» fue el marqués de Manzanedo y, posteriormente, primer duque de Santoña, que había firmado para contrarrestar la protesta, junto a un numeroso grupo de conservadores, moderados y esclavistas en general, el manifiesto de la Liga Nacional, ${ }^{67}$ que se publicó, en toda su extensión, en las primeras páginas de varios periódicos. En él se ponía de relieve, entre otros factores, el peligro de emprender una reforma radical de la situación, es decir, de la esclavitud, en un momento en el que las Antillas españolas vivían bajo la agitación revolucionaria, representada por el desarrollo de la Guerra Grande en Cuba. «Los proyectos iniciados por el Gobierno no darán otro fruto», venía a concluir el texto mencionado, «que poner en manos de los rebeldes los recursos morales y políticos que necesitan para robarnos el prestigio, la confianza, la unidad, el pan y la pólvora». La sombra de Toussaint-Louverture, héroe de la independencia haitiana, seguía paseándose, orgullosa, por las cumbres del Caribe, es decir, el «miedo al negro» que generaron en determinados sectores los acontecimientos revolucionarios de Santo Domingo-Haití. ${ }^{68}$

Algunos periódicos contrarios al proyecto abolicionista no dudaron en situar, en medio del «grupo de más importancia, compuesto de diputados y senadores radicales, una bandera azul y blanca, algo arrollada para ocultar la estrella solitaria que constituye con aquellos colores la bandera de la insurrección cubana». El Pensamiento Español añadió que no sabía si la noticia era cierta y que «bien pudiera ser también la bandera, algún pendón masónico». ${ }^{69}$ Pudo tratarse, concretamente, del «estandarte de los Comuneros, nombre con que se distingue una logia masónica». ${ }^{70}$

66 «El Trágala», El Pensamiento Español, Madrid, 14 de enero de 1873, 1. El Imparcial, Madrid, 14 de enero de 1873, 2. En relación con Sagasta existe abundante bibliografía respecto a su alta personalidad masónica y política. En 1876 fue nombrado gran comendador y gran maestre del GODE. Álvarez Lázaro, 1987, I: 31-32; 2006, 358-362; 2012, 138, 139, 146. Ferrer Benimeli, 2007, 101-165; 2013, 114-115.

67 «Manifiesto», La Iberia, 14 de enero de 1873, 1-2. Entre los firmantes se destacan los nombres de Antonio Cánovas del Castillo y Francisco Romero Robledo. Este último era suegro de Zulueta que, según La Discusión (8 de marzo de 1873, 1), tenía más de tres mil esclavos africanos en sus ingenios de Cuba. La Nación, 16 de enero de 1873, 2, se refirió a la Liga como la «Liga negrera que se dice nacional».

68 Naranjo Orovio y Buscaglia, 2015.

69 El Pensamiento Español, 14 de enero de 1873, 3.

70 La Iberia, 14 de enero de 1873, 4. Figura descrito, asimismo, en La Discusión, 14 de enero de 1873,3 . 


\section{Debates periodísticos en torno a la manifestación madrileña del 12 de enero de 1873}

Los medios que se oponían a las reformas no solo trataron de aminorar, en primer término, el número de participantes en la marcha, ${ }^{71}$ sino que destacaron la presencia de la masonería mediante el citado estandarte de la logia Los Comuneros de Castilla, ${ }^{72}$ un taller al que ya nos hemos referido en relación con Nicolás Díaz y Pérez. La Esperanza llegó a afirmar que debía tenerse en cuenta que «la masonería está en Madrid muy extendida, y que se ha declarado partidaria de las reformas propuestas por el Gobierno». ${ }^{73}$ Pero, en estos medios conservadores, el asunto ya venía de antes.

En efecto, entre finales de 1872 y principios del año siguiente, tanto La Esperanza como La Regeneración, por citar dos ejemplos significativos, incluyeron en las primeras páginas referencias a la conexión entre abolicionismo, reformas en Puerto Rico y masonería. La Esperanza se hizo eco de un suelto de La Tertulia, en el que se negaban estas afirmaciones, basadas en el hecho discutido de que tanto Ruiz Zorrilla, como el rey de España y el de Italia eran «masones y únicos motores de aquellas reformas». Pero, en cualquier caso, había señalado también La Esperan$z a$, «aunque la cosa no sea cierta», resultaba creíble que, si la masonería trabajaba por el «progreso y la libertad y en favor de la fraternidad, nada tiene de extraño que hubiera trabajado por las libertades de las provincias ultramarinas». ${ }^{74}$ La Esperanza también publicó, unos días más tarde, un artículo de Valentín de Novoa, «abogado y escritor tradicionalista», ${ }^{75}$ remitido desde Orense, en el que acusaba directamente a la masonería de la pérdida de la América continental española y de cuantos males amenazaban a la Iglesia católica y a la integridad de la patria. ${ }^{76}$ La Regeneración no dudó en interpretar la manifestación del 12 de enero de 1873 en clave masónica. La abolición de la esclavitud y las reformas de Puerto Rico no eran, según decía, una expresión de «amor a la humanidad»ni

71 La Iberia, 18 de enero de 1873, 2. En «La manifestación», La Regeneración, Madrid, 13 de enero de 1873, 1-2, se situó la cifra en unas 3000 personas, el uno por ciento de la población de la capital.

72 El Imparcial, 13 de enero de 1873, 1.

73 La Esperanza, 13 de enero de 1873, 2.

74 La Esperanza, 18 de diciembre de 1872, 2.

75 Martín Sánchez, 2007, I: 191.

76 «Quiénes pueden salvar España», La Esperanza, 31 de diciembre de 1872, 1-2. 
de «filantropía negrera», así como tampoco del espíritu de buen gobierno ni del entusiasmo por la libertad, sino una respuesta a los compromisos contraídos con «naciones extranjeras que os han ayudado a nefandas revoluciones». Los elementos que defendían las reformas estaban ligados, más bien, «con juramentos execrables en vuestras logias masónicas, red inmensa que enreda a España y paraliza a Europa y abarca el Nuevo Mundo». ${ }^{77}$

La prensa progresista, por su parte, no tuvo dificultad en reconocer que, desde siempre, entre sus principios democráticos, destacaban la supresión de la pena de muerte y la eliminación de la esclavitud. ${ }^{78} \mathrm{La}$ América de los hermanos Asquerino subrayó que, desde hacía dieciséis años, habían defendido la abolición de la esclavitud. ${ }^{79}$ Se dedicaron sesudos artículos al problema en las Antillas y en Brasil, se planteó con claridad que el objetivo de la manifestación era llevar a cabo «las reformas de Ultramar»y, especialmente, «la abolición inmediata de la esclavitud en Puerto Rico» ${ }^{80}$ Se negó la existencia de una bandera insurrecta cubana en la manifestación ${ }^{81}$ pero se reconoció que había circulado un «estandarte morado guarnecido de hilo de plata, en cuyo fondo se leía: Los Comuneros», entre otros títulos emblemáticos..$^{82}$ Disuelta ya la marcha, una serie de representantes pasaron a la Presidencia del Gobierno a «felicitar al Sr. Ruiz Zorrilla». La comisión estaba compuesta por miembros de la Tertulia radical, de la SAE y representantes de la prensa. Sorní declaró entonces que «los republicanos estarían al lado del gobierno en esta como en cuantas cuestiones afectaran a la libertad». El general Carmona, Aníbal, otro destacado miembro de la masonería, ofreció el apoyo de la Milicia, «así dentro como fuera de Madrid». Se destacó también la inexistencia de la «menor sombra de desorden a pesar de una afluencia inusitada». ${ }^{83}$ En la cabecera de la marcha habían estado presentes, invitados por los organizadores, algunos ciudadanos negros y mulatos que, por aquel entonces, residían en la capital de España.

77 «Las reformas de Puerto-Rico. Artículo VIII. Abolición de la esclavitud», La Regeneración, 13 de enero de 1873, 1.

78 La Discusión, 19 de noviembre de 1868, 2.

79 La América, XVII:1, 13 de enero de 1873, 16.

80 La Discusión, 10 de enero de 1873, 1-2.

81 La Discusión, 17 de enero de 1873, 1.

82 «La manifestación abolicionista», La Nación, 14 de enero de 1873, 1.

83 La Época, 13 de enero de 1873, 2-3. La Nación, 14 de enero de 1873, 2. 


\section{Movilizaciones en el resto de España}

El ejemplo de Madrid cundió en otros lugares. Las manifestaciones se extendieron por las calles de numerosas ciudades españolas como un reguero de pólvora. En algún caso se exteriorizó igualmente la presencia de alguna logia masónica y en ciertos enclaves los radicales y republicanos se habían adelantado a la marcha de Madrid. El corresponsal de La Época en Zamora, por ejemplo, aunque parecía solidarizarse con el temor de un sector destacado de la población que no las tenía todas consigo respecto al futuro del comercio colonial, debido sobre todo a la «sospechosa inconsecuencia» del Gobierno, no dejó de ponderar con interés la protesta zamorana. En efecto, el centenar de personas que habían salido a la calle a favor de las reformas ultramarinas lo había hecho, según decía, para contrarrestar la difusión de «una notable exposición suscrita por la casi totalidad de los vecinos de Zamora», en el sentido de no precipitar las reformas. Sin embargo, el corresponsal no dudó en calificar la manifestación progresista de «elocuentísima», aunque lo más notable de su crónica fue que, aparte de mencionar la presencia de empleados públicos entre los militantes radicales y republicanos, destacó también que «entre los lemas y banderas descollaba la de los masones, en primer término, como si en ella rindieran todos acatamiento». ${ }^{84}$

Los republicanos de Valencia, sin embargo, no habían tenido mayores dificultades a la hora de abarrotar las calles de la ciudad. Como había sucedido en Madrid, la prensa menos identificada con las reformas bajaba las cifras de diez mil ${ }^{85}$ a unas dos mil personas, ${ }^{86}$ quienes no solamente pedían las reformas para Puerto Rico sino también para Cuba. «Este es un nuevo Trágala que preparan los enemigos de la patria». ${ }^{87}$ La Nación sostenía, en paralelo a La Discusión, que la cifra de manifestantes había superado las diez mil personas, y que tanto el gobernador civil como el jefe ad honorem del partido republicano y otras personalidades se habían dirigido al gentío con magníficos discursos ${ }^{88}$ a favor de las reformas ultramarinas.

Una de las mejores descripciones de la marcha del Turia fue la del corresponsal de La Igualdad, que no tuvo inconveniente en destacar desde

84 La Época, 10 de enero de 1873, 2.

85 Así lo había difundido, por ejemplo, La Discusión, 14 de enero de 1873, 3.

86 El Imparcial, 15 de enero de 1873, 3.

87 La Época, 14 de enero de 1873, 4.

88 La Nación, 14 de enero de 1873, 1-2 y 16 de enero de 1873, 2. 
el principio aspectos de especial interés político como, por ejemplo, las divisiones internas entre los federales. Subrayó sin ambages el carácter abolicionista de la protesta; indicó con rotundidad, respecto a las cifras, que la marcha a la altura de La Glorieta no bajaba de las tres mil personas y que, cuando los manifestantes llegaron al edificio del Temple, residencia del gobernador, no había menos de ocho mil. Entre los asistentes se contaban numerosos militantes republicanos, radicales y empleados públicos y, como había sucedido en Madrid, al final del recorrido el ciudadano Guerrero, «con más fe y entusiasmo que claros conceptos», se dirigió a los congregados. Posteriormente, el propio gobernador, Sr. Charques, pronunció un discurso que la multitud interrumpió con «bravos y aplausos»y, asimismo, con unos cuantos «mueras a la Liga» llamada esclavista, que contrastaban con los abundantes «vivas que se dieron a la libertad». ${ }^{89}$

En Lérida, no menos de setenta y cinco ciudadanos, entre los que se contaban médicos, abogados, propietarios, cargos concejiles y diputados provinciales firmaron un manifiesto, el 11 de enero de 1873, bajo el expresivo título de «Abajo la esclavitud». En uno de cuyos párrafos se leía: «Idólatras nosotros de la honra y del buen nombre de nuestra querida España, profundamente convencidos de que de la práctica de la justicia no puede emanar sino el bien», se sentían impulsados a rubricar el texto «ante la oposición desatentada y furiosa» que la Liga Nacional suscitaba «contra la ley que para la inmediata libertad de los esclavos de Puerto Rico está presentada a las Cortes». Se trataba, añadían, de cumplir con un alto deber de patriotismo, de justicia y de humanidad «adhiriéndonos a la Sociedad Abolicionista Española e invitando, como invitamos, a todos los buenos liberales» al objeto de constituir un comité local abolicionista para contribuir a la causa emancipadora. A tal fin tenían previsto reunirse el domingo, 19 de enero de 1873, en el salón de los Campos Elíseos. ${ }^{90}$

El ambiente se había venido preparando en toda España desde semanas antes de las marchas que tuvieron lugar en diferentes enclaves del país. Con el año nuevo, La Discusión se hacía eco de la multitud de «exposiciones» que habían llegado a las Cortes desde los más diversos lugares. ${ }^{91}$ Las

89 La Igualdad, Madrid, 15 de enero de 1873, 1-2.

90 La Discusión, 19 de enero de 1873, 2.

91 La Discusión, 1 de enero de 1873, 3. Entre otras las que impulsaron las sociedades abolicionistas de León, Málaga y Sevilla, así como diversos grupos vecinales y ayuntamientos como los de Lora del Río, Tortosa, Santander, Cartagena, Badajoz, Ciudad Real, etc. La Nación, 16 de enero de 1873, 2, publicó un extracto de la que habían elaborado los radicales de Loja, el 6 de enero de 1873. Fernández Canales, 1987, 158-159. 
adhesiones también se dirigieron a personalidades muy singulares como el propio Castelar, ${ }^{92}$ autor de un famoso discurso contra la esclavitud, al que felicitaban por su defensa de la causa abolicionista. ${ }^{93}$ Paralelamente, se anunciaron y publicitaron concurridos mítines antiesclavistas en Pontevedra, Zaragoza y Sevilla. ${ }^{94}$ El 19 de enero se celebraron también manifestaciones a favor de las reformas de Ultramar en Santander, Jaén, Cartagena, Alicante y Burgos. ${ }^{95}$ Sería interesante elaborar un recuento, lo más preciso posible, de la participación de miembros de la masonería en este tipo de eventos y, desde luego, en las propias organizaciones abolicionistas.

En la SAE de Sevilla por ejemplo no es difícil observar, en 1872 y 1873, la presencia de destacados krausistas ${ }^{96} \mathrm{y}$, asimismo, de masones de relieve como el mismo presidente, Antonio Machado y Núñez, Toby, grado 31 y venerable de su logia desde antes de 1873, abuelo de los famosos poetas Antonio y Manuel Machado. ${ }^{97}$ El segundo vicepresidente, Joaquín Casanovas Ferrán, Moncada, grado 20 que también ostentó la veneratura de su taller, propietario, lo mismo que Machado. ${ }^{98}$ Entre los vocales, Manuel García Peña, Roger, grado 6 del REAA, que ya poseía en 1876, y había sido primer vigilante con Casanovas; ${ }^{99}$ o Teófilo Martínez de Escobar, Platón, grado 18 en 1873 que no tardó en pasar a La Habana como catedrático de su Universidad, ${ }^{100}$ desde donde regresó a Las Palmas de Gran Canaria, su ciudad natal, en fechas previas a $1912 .{ }^{101}$ Eclesiástico en sus orígenes, pertenecía a una importante saga familiar isleña. Dos de sus hermanos carnales, Amaranto y Emiliano, fueron igualmente destacados masones de la logia Afortunada (GOLU), de Las Palmas, desde $1870 .{ }^{102}$

Entre los miembros y colaboradores de la SAE en la capital de España, incluyendo aquellos que participaban activamente en mítines y

92 Su adscripción masónica es discutible, al tratarse de un nombramiento honorario. Morayta, 1915, 212. Paz Sánchez, 2008, 78-79. Ferrer Benimeli, 2010, I: 9. Ruiz Sánchez, 2010, I: 33-34. Otero, 2010, I: 402.

93 La Discusión, 21 de enero de 1873, 2.

94 La Discusión, 26 de enero de 1873, 2.

95 El Imparcial, 20 de enero de 1873, 2.

96 Gómez Zarzuela, 1873, 294. Sánchez-Gey y Paz Sánchez, 1988, 50-51. Entre los krausistas, Federico de Castro y Teófilo Martínez de Escobar. Los mismos miembros de la directiva de la SAE de Sevilla, en 1872.

97 Enríquez del Árbol, 2011, 105, 118, 122, 218, 746.

98 Ibidem, 144, 145, 151, 152, 203, 725.

99 Ibidem, 144, 146, 149, 153.

100 Ibidem, 154, 177, 199, 211, 747.

101 Sánchez-Gey y Paz Sánchez, 1988, 50.

102 Paz Sánchez, 1984, 831-832. 
manifestaciones, que rubricaban importantes manifiestos o «exposiciones» y que defendían las tesis abolicionistas en las Cortes, se cuentan desde luego otros muchos masones. A la manifestación del 12 de enero de 1873, a la que ya nos hemos referido ampliamente, se sumó también el tinerfeño Luis Francisco Benítez de Lugo, VIII marqués de La Florida, masón, espiritista y amigo personal de Ruiz Zorrilla, diputado en 1872 y $1873 .{ }^{103}$ Otros varios personajes de la época, implicados en las luchas contra la esclavitud y obreros de la colmena masónica, fueron o al menos existen indicios creíbles de su vinculación a la orden, José M. Carrascón y Abad, diputado por Zaragoza, vocal fundacional de la directiva de la SAE, compañero de Castelar en la prensa, que fue tenido también por carbonario. ${ }^{104}$ Eduardo Chao Fernández, diputado republicano varias veces por Orense y Pontevedra, durante el Sexenio; ministro de Fomento en 1873, quien perteneció de manera reiterada a la dirección de la SAE. ${ }^{105}$ Otro personaje relevante que, si no lo fue es posible que estuviera muy próximo a serlo, fue el demócrata histórico Bernardo García que también dirigió La Discusión, el periódico fundado por Nicolás María Rivero. Perteneció a la SAE y participó en la manifestación del 12 de enero de 1873, en Madrid. ${ }^{106}$ También estuvo vinculado a la SAE Manuel Merelo Calvo, Daniel, grado 18, diputado demócrata del Sexenio, miembro del Consejo de Estado y senador, amigo de Sagasta; profesor y periodista. ${ }^{107}$ José Navarrete, como pasa con Bernardo García y tantos otros, tampoco es seguro que fuera masón pero se sabe que lo mismo que su amigo Benítez de Lugo pertenecía a una agrupación espiritista. En 1900 quería suprimir las corridas de toros y su campaña tuvo cierto eco en la prensa, pero escaso recorrido. Había sido fundador de la SAE y diputado en 1872 y, como mínimo, ostentó la graduación de comandante de Artillería. ${ }^{108}$

Ignacio Rojo Arias, Justiniano, figura entre los senadores que apoyaron las tesis abolicionistas. Su adscripción masónica no ofrece lugar a dudas, pues en momentos de disidencia interna, mediada la década de 1880, llegó a tener una obediencia con variante nominal específica, según la nomenclatura de las potencias históricas de la masonería española: GODER

103 Guimerá Peraza, 1982. Alvarado Planas, 2016, 292-295.

104 Díaz y Pérez, 1894, 478. Morayta, 1915, 213.

105 Díaz y Pérez, 1894, 460. Morayta, 1915, 213. Vaquero, 1993, II: 1090-1092. Randouyer, 2004, I: 23. Valín, 2008, 130-133.

106 Morayta, 1915, 214. Randouyer, 1985, 76. Chato, 2010, I: 80, 84. Higueras, 2016, 322.

107 Morayta, 1915, 214. Domingo Acebrón, 1995, I: 35-36, 38.

108 Morayta, 1915, 215. García Baena, 2007, II: 1253-1254. El Liberal, 22 de agosto de 1897, 1. La Ilustración Española y Americana, XXXII, Madrid, 30 de agosto de 1900, 116. 
(Gran Oriente de España de Rojo Arias). Ocupó, además, el cargo de soberano gran comendador del Supremo Consejo del 33, al producirse la dimisión de Manuel Becerra, Fortaleza, y, entre otras tareas políticas, fue gobernador civil de la capital de España. ${ }^{109}$ Becerra, por su parte, ocupó varias veces la cartera de Ultramar.

El general y diputado de las Cortes septembrinas (1869-1872), Blas Pierrad Alcedar, perteneció a ambas organizaciones, a la SAE y a la orden del GADU, y fue elegido vicepresidente de la primera en 1868. En masonería, según Díaz y Pérez, ocupó la veneratura de la logia Fraternidad (GOLU) de la capital de España y había tomado parte «muy activa» en el triunfo de la revolución. Morayta lo definió como un masón muy calificado. ${ }^{110}$ Otro general, diputado en Cortes del Sexenio, posiblemente masón y, con seguridad, abolicionista fue Lorenzo Miláns del Bosch, vicepresidente de la SAE en 1871, bajo la presidencia de Fernando de Castro, cuando también Morayta formaba parte del equipo. Ambos firmaron, como es natural, el manifiesto antiesclavista dirigido a la nación del 12 de febrero de $1871 .{ }^{111}$

Con base al inventario de representantes y altos cargos pertenecientes a la orden que publicó Morayta en 1915 y que de alguna manera tuvieron relación con la SAE o, en general, con el movimiento abolicionista español, cabe citar asimismo los nombres de Francisco García López, ${ }^{112}$ uno de los vicepresidentes de la agrupación antiesclavista en 1868; Gregorio García Ruiz ${ }^{113}$ quien fue vocal fundacional de la entidad abolicionista, el 2 de abril de 1865, y José Güell y Renté, que casó con una Infanta de España, Josefa Fernanda de Borbón, intervino en los sucesos políticos del Sexenio y tuvo una existencia bastante novelesca. Senador por la Universidad de La Habana, donde había nacido, La República destacó, cuando publicó su necrológica, que «era uno de los individuos más activos de la Sociedad Abolicionista Española», lo que parece un poco exagerado, pero adecuado para la ocasión. ${ }^{114}$

109 Díaz y Pérez, 1894, 214, 492, 615. Morayta, 1915, 213. Álvarez Lázaro, 1987, I: 32-34 55; 2012, 139-140, 146. Ferrer Benimeli, 2007, 19-20; 2010, I: 8-9, $12,18$.

110 Díaz y Pérez, 1894, 428. Morayta, 1915, 209, 214. Randouyer, 1985, 60, 91. Paz Sánchez, 2008, 51-57. Alvarado Planas, 2016, 228. García-Municio de Lucas, 2017, 252, 346.

111 La América, XV:4, 26 de febrero de 1871, 5-6. Díaz y Pérez, 1894, 492, 549. Morayta, 1915, 214. Randouyer, 1985, 60, 85. Longobardo, 2004, II: 855. Chato, 2010, I: 92. Alvarado Planas, 2016, 228. García-Municio de Lucas, 2017, 338.

112 Morayta, 1915, 213.

113 Idem.

114 Ibidem, 1915, 139. La República, Madrid, 21 de diciembre de 1884, 2. 
Morayta también sitúa, entre los Hijos de la Viuda, al marqués de Montemar, Francisco de Paula Montemar y Moraleda, ${ }^{115}$ quien llegaría a presidir la directiva del partido republicano progresista y, por otra parte, había sido vocal fundacional de la SAE en la primavera de 1865, diputado en Cortes y senador durante el Sexenio; y a Manuel Regidor Jurado, ${ }^{116}$ diputado por Puerto Rico en 1873, según el registro del Congreso de los Diputados. Otro masón y abolicionista destacado, entre los representantes borinqueños, fue Román Baldorioty de Castro. ${ }^{117}$ Por su lado, el diputado por Castellón, en 1871-1872, Facundo de los Ríos Portilla, discípulo de Sanz del Río, cimbrio y gobernador civil de Castellón y Barcelona, participó también en la manifestación abolicionista del 12 de enero de 1873. Morayta no duda en integrarle entre los miembros de la orden, ${ }^{118}$ lo que no sería de extrañar. Otro de los manifestantes fue el abogado y diputado por Segovia, en 1871 y 1872, Salvador Saulate Matesanz, que nuestro autor y emblemático gran maestre del GOE asegura, asimismo, que también «vio la luz». ${ }^{119}$ Pero, con todo, aparte de marchas, conferencias y mítines también determinados miembros de la orden volvieron a utilizar la cultura como una herramienta de transformación de la sociedad.

\section{Otros aspectos socioculturales}

Se celebraron, en efecto, otras actividades de dinamización cultural y eventos literarios como el certamen poético organizado por la propia SAE, en el que participaron varios autores y algunas autoras, y que ganó la composición titulada «La esclavitud de los negros» de Concepción Arenal, ${ }^{120}$ probablemente la mejor de las presentadas. Los diecisiete poemas seleccionados fueron compilados en un libro que, en 1866, publicó la SAE, bajo el título genérico de El cancionero del esclavo. Otros autores y autoras publicaron también, por aquellos años, algunos poemas abolicionistas en la prensa más o menos afín. Eusebio Asquerino por ejemplo dedicó uno de ellos, el 3 de agosto de 1870, a Emilio Castelar, con algunas figuras de sabor masónico. Aludía, así, al «símbolo sagrado», a la «armonía» en dos

115 Díaz y Pérez, 1894, 484, 489. Morayta, 1915, 214. Martínez de las Heras, 2007, I: 223.

116 Morayta, 1915, 215.

117 Ayala, 1991, 182. Otero, 2010, I: 406.

118 Morayta, 1915, 214.

119 Idem.

120 Lacalzada de Mateo, 1993. Pozuelo, 1988, 86-90. Vila Vilar, 2014, 235-261. 
ocasiones, a la conciencia y al libre albedrío, a los «tiernos lazos» de la familia, a la opresión del «hermano», a la unidad del género humano: «la humanidad entera / por fibras misteriosas está unida», a la venganza ruda de «quien destruye del hombre la armonía», a la esclavitud como afrenta de la razón y, en fin, al amor al bien del tribuno que hacía que en el azul del cielo se derramase «de la fraternidad risueña aurora». ${ }^{121}$

En el ámbito teatral se estrenó también, el 14 de enero de 1873, el drama antiesclavista del republicano federal Luis Blanc Navarro, Romper cadenas. ${ }^{122}$ Más que la obra en sí, aunque las críticas no fueron malas al contrario de lo sucedido con Cora o la esclavitud, quizás lo más interesante fue el enfoque propagandístico que se le quiso dar «a favor de la libertad del negro», por lo que la SAE invitó al pueblo de Madrid «para que asista a las representaciones de esta obra, que motivará nuevas manifestaciones en pro de las reformas ultramarinas». No se trataba, se apuntaba también en La Discusión, de un drama de «relumbrón», sino más bien de «un cuadro de costumbres en el que campean sentimientos altamente humanitarios». ${ }^{123}$

La SAE aprovechó el estreno para convocar una manifestación en el propio Teatro Novedades, una especie de eco cultural de la marcha que acababa de cruzar, apenas dos días antes, las principales calles de la capital de España. ${ }^{124} \mathrm{Al}$ terminar la representación se leyeron varias poesías «a la abolición de la esclavitud», entre las felicitaciones al autor de la obra, las galanterías de la SAE y la presencia de numerosas personas que halagaban al comediante, entre ellas varios cubanos. ${ }^{125}$ El drama, según coincidía la crítica, abundaba en situaciones de «gran efecto» que fueron muy aplaudidas. ${ }^{126}$ Otros escritores dramáticos preparaban a la sazón sus composiciones, como la que había inspirado don Vicente Ramos a un «reputado escritor», que llevaría el título de El 24 de diciembre o la abolición de la esclavitud, un drama de connotaciones religiosas, lo mismo que otros de su autor que también escribió zarzuelas, juguetes cómicos y teatro infantil. ${ }^{127}$ Resultaba

121 Eusebio Asquerino, «La abolición de la esclavitud», La América, XVII:2, 28 de enero de $1873,14$.

122 Pozuelo, 1988, 90-92.

123 «Noticias varias», La Discusión, 12 de enero de 1873, 3 .

124 El Imparcial, 14 de enero de 1873, 3.

125 La Correspondencia de España, 15 de enero de 1873, 2. La Nación, 15 de enero de 1873,3 .

126 La Discusión, 19 de enero de 1873, 1.

127 El Imparcial, 13 de enero de 1873, 2. Ruibal, 1997, 1061. 
evidente en cualquier caso que algunas puestas en escena, al margen de su calidad y de las valoraciones de la crítica especializada, se convirtieron en un instrumento cultural al servicio de las luchas contra la esclavitud.

\section{Conclusiones}

Numerosos miembros de la masonería, a través de sus logias y de otros organismos masónicos, o bien de manera individual se sumaron de forma creciente a la causa de la libertad de los últimos esclavos legales en suelo colonial y, al mismo tiempo, profundamente español: Cuba y Puerto Rico. No solamente integraron, desde los primeros momentos, las filas de la SAE a la que contribuyeron a sostener, dinamizar y definir en sus perfiles más radicales y progresistas, sino que también promovieron la implantación de entidades afines en diversos lugares de España. En tal sentido parecen haber adquirido cierto protagonismo en la realización de mítines, concentraciones, manifestaciones, exposiciones y peticiones a las autoridades, especialmente durante la etapa democrática generada por la revolución de septiembre de 1868 y el consiguiente período de reformas institucionales y culturales.

Por otra parte, un sector en principio minoritario de la orden parece que se dejó seducir por una fórmula de transición de la esclavitud a la libertad aparentemente menos onerosa para los intereses de la Hacienda pública y especialmente de los hacendados cubanos, actitud que estaba basada, según se argumentó, en los peligros inherentes al estallido de la Guerra Grande en Cuba. Pero, pese a todo, la presión pública y las vindicaciones continuaron por parte de la SAE y de otros colectivos sociopolíticos hasta que se conquistó la emancipación plena para los esclavos de las Antillas españolas, casi una década antes del estallido de la Guerra de Independencia en la Gran Antilla. En este contexto, numerosos masones, insulares y peninsulares, lucharon a este lado del Atlántico por la libertad de sus hermanos negros, a los que nunca negaron su presencia en los talleres masónicos, entre otras razones porque los estatutos masónicos vigente en España no reconocían diferencias étnicas. Además, se pusieron en marcha para la formación y la transformación del imaginario cultural, diversas actividades de dinamización de las que son buena prueba los estrenos de algunas obras de teatro antiesclavista, así como los concursos y recitales poéticos o, también, los textos abolicionistas que, poco a poco, contribuyeron a reforzar 
los sentimientos de solidaridad y de libertad en los corazones de muchos ciudadanos españoles. La participación en mítines y reuniones, en los foros políticos y en la calle, desde el inconformismo, la disidencia y la confrontación de ideas propia de toda sociedad libre, crearon las bases que convirtieron en leyes algunos de los principios democráticos sobre los que no pocos masones habían debatido en las más nobles tenidas de los talleres en los que habían visto la luz.

Recibido, 4 de noviembre de 2020 Segunda versión, 24 de enero de 2021 Aceptado, 16 de febrero de 2021

\section{Referencias bibliográficas}

Alvarado Planas, Javier, Masones en la nobleza de España, Madrid, La Esfera de los Libros, 2016.

Álvarez Lázaro, Pedro, «Pluralismo masónico en España», en Ferrer Benimeli, José A. (coord.), La masonería en la España del siglo XIX, Salamanca, Centro de Estudios Históricos de la Masonería Española (CEHME), 1987, vol. I, 19-56.

Álvarez Lázaro, Pedro, «El eco de la cuestión colonial en la educación masónica de la España metropolitana de fin de siglo XIX», Revista de Educación, Extra 1, Salamanca, 1997, 177-190.

Álvarez Lázaro, Pedro, Páginas de historia masónica, Tenerife, Idea, 2006.

Álvarez Lázaro, Pedro, La masonería, escuela de formación del ciudadano, Madrid, Comillas, 2012.

Arias Castañón, Eloy y Enríquez del Árbol, Eduardo, «Masonería y política en la Sevilla del Sexenio democrático (1868-1874)», en Ferrer Benimeli, José A. (coord.), Masonería, política y sociedad, Córdoba, CEHME, 1989, vol. I, 35-54.

Arroyo Jiménez, Paloma, «La Sociedad Abolicionista Española, 1864-1886», Cuadernos de Historia Moderna y Contemporánea, 3, Madrid, 1982, 127-150.

Arroyo Jiménez, Paloma, «La Sociedad Abolicionista Española (1864-1886)», en Solano Pérez-Lila, Francisco de Paula y Guimerá Ravina, Agustín (eds.), Esclavitud y derechos humanos: la lucha por la libertad del negro en el siglo XIX, Madrid, CSIC, 1990, 169-182.

Ayala, José A., La masonería de obediencia española en Puerto Rico en el siglo XIX, Murcia, Universidad de Murcia, 1991.

Barbier, Jules, Cora ou L'Esclavage, París, Fréres, 1861.

Burke, Peter, Historia y teoría social, Buenos Aires, Amorrortu, 2007.

Caballero de Puga, Eduardo, Datos biográficos del sexto gran maestre, gran comendador del Grande Oriente Nacional de España, Madrid, s. n., 1883. 
Castellano, Juan R., «La Sociedad Abolicionista Española y la abolición de la esclavitud en Cuba y Puerto Rico», Hispanófila, 23, North Carolina, 1965, 9-22.

Chato Gonzalo, Ignacio, «Españoles en Portugal: exilio, emigración y masonería (1843-1868)», en Ferrer Benimeli, José A. (coord.), La masonería española, represión y exilios, Almería, CEHME, 2010, vol. I, 71-95.

Cooper, Bárbara T., «Cora, ou L'Esclavage: a French anti-slavery drama set against the backdrop of the American Civil War», CLA Journal, 45:3, Estados Unidos, 2002, 360-378.

Cruz Artacho, Salvador, Andalucía en la utopía federal de España, Sevilla, Centro de Estudios Andaluces, 2016.

Díaz y Pérez, Nicolás, La francmasonería española. Ensayo histórico-crítico de la Orden de los francmasones en España desde su origen hasta nuestros días, Madrid, Ricardo Fe, 1894.

Domingo Acebrón, María D., «Víctor Patricio Landaluze, un pintor español, masón y anti-independentista en Cuba, en la primera mitad del siglo XIX», en Ferrer Benimeli, José A. (coord.), La masonería española entre Europa y América, Zaragoza, CEHME, 1995, vol. I, 31-40.

Domingo Acebrón, María D., «Rafael María de Labra y su relación con la masonería en Madrid y en Cuba (1880-1918)», en Ferrer Benimeli, José A. (coord.), La masonería en Madrid y en España del siglo XVIII al XXI, Leganés, CEHME, 2004, vol. II, 833-841.

Domingo Acebrón, María D., Rafael María de Labra, Cuba, Puerto Rico, Las Filipinas, Europa y Marruecos, en la España del Sexenio Democrático y la Restauración (1871-1918), Madrid, CSIC, 2006.

Enríquez del Árbol, Eduardo, La masonería en Sevilla y provincia en el último tercio del siglo XIX, Sevilla, Diputación de Sevilla, 2011.

Estévanez y Murphy, Nicolás, Mis memorias, Madrid, Tebas, 1975.

Fernández Canales, Consuelo, «Exposiciones de la opinión pública ante la abolición de la esclavitud en Puerto Rico (1868-1873)», Cuadernos de Historia Moderna y Contemporánea, 8, Madrid, 1987, 157-171.

Ferrer Benimeli, José A., Jefes de Gobierno masones. España 1868-1936, Madrid, La Esfera de los Libros, 2007.

Ferrer Benimeli, José A., «Nicolás Salmerón y Alonso (1837-1908) y su presunta vinculación con la masonería», en Ferrer Benimeli, José A. (coord.), La masonería española, represión y exilios, Almería, CEHME, 2010, vol. I, 3-21.

Ferrer Benimeli, José A., La Masonería, Madrid, Alianza Editorial, 2013.

Ferris, Kate, «Modelos de abolición: Estados Unidos en la política cultural española y la abolición de la esclavitud en Cuba, 1868-1874», en Blanco, Alda y Thomson, Guy (eds.), Visiones del liberalismo, Valencia, Universitat de València, 2008, 195-218.

Galván Rodríguez, Eduardo, La abolición de la esclavitud en España. Debates parlamentarios, 1810-1886, Madrid, Dykinson, 2014. 
García Baena, Rosa M., «Los Poza Juncal. Una familia expedientada», en Ferrer Benimeli, José A. (coord.), La masonería española en la época de Sagasta, CEHME, Logroño, 2007, vol. II, 1241-1258.

García-Municio de Lucas, Ezequiel I., «Militares y masonería», tesis doctoral dirigida por los drs. Gonzalo Álvarez Chillida, Isabel Martín Sánchez y R. Geoffrey Jensen, Universidad Complutense de Madrid, 2017. Disponible en: https://eprints.ucm.es/id/eprint/49518/1/T40358.pdf [Consultado: 14/10/2020].

Gómez Zarzuela, Manuel, Guía de Sevilla, su provincia, etc., para 1873, Sevilla, La Andalucía, 1873.

Guimerá Peraza, Marcos, El radical marqués de La Florida (1837-1876), Tenerife, Aula de Cultura, 1982.

Hernández González, Manuel, «Introducción», en Pérez Carrión, José A., Los canarios en América, Tenerife, Idea, 2004, 11-41.

Hernández Paz, Miguel D., Andrés Orihuela Moreno y El Sol de Jesús del Monte, Tenerife, Ediciones Idea, 2007.

Higueras Castañeda, Eduardo, Con los Borbones, jamás. Biografía de Manuel Ruiz Zorrilla (1833-1895), Madrid, Marcial Pons, 2016.

Labra, Rafael M. de, «Don Fernando de Castro», Revista de España, 122, Madrid, 1888, 380-397.

Lacalzada de Mateo, María J., «Concepción Arenal: por la abolición de la esclavitud y a favor de la emancipación de la persona humana», en Ferrer Benimeli, José A. (coord.), Masonería española y América, Zaragoza, CEHME, 1993, vol. II, 737-747.

Lacalzada de Mateo, María J., «Presencia femenina en la masonería extremeña durante el último tercio del siglo XIX», en Cortijo, Esteban (coord.), Masonería y Extremadura, Cáceres, Ateneo, 2008, 121-156.

Longobardo Carrillo, Julio, «Manuel de Llano y Persi, un político y masón desconocido», en Ferrer Benimeli, José A. (coord.), La masonería en Madrid y en España del siglo XVIII al XXI, Leganés, CEHME, 2004, vol. II, 843-869.

López-Ocón Cabrera, Leoncio, «El movimiento abolicionista español a través de la revista "La América" (1857-1886)», en Solano Pérez-Lila, Francisco de Paula y Guimerá Ravina, Agustín (eds.), Esclavitud y derechos humanos: la lucha por la libertad del negro en el siglo XIX, Madrid, CSIC, 1990, 205-246.

Martín Sánchez, Isabel, «La imagen masónica de Sagasta a través de la prensa satírica de finales del siglo XIX», en Ferrer Benimeli, José A. (coord.), $L a$ masonería española en la época de Sagasta, Logroño, CEHME, 2007, vol. I, 175-205.

Martínez de las Heras, Agustín, «El Voto Nacional (1881-1882) de Ramón Chíes: un diario filomasónico y republicano», en Ferrer Benimeli, José A. (coord.), La masonería española en la época de Sagasta, Logroño, CEHME, 2007, vol. I, 207-240. 
Martínez López, Fernando, Masones, republicanos y librepensadores en la Almería contemporánea (1868-1945), Almería, Editorial Corduba/Universidad de Almería, 2010.

Morayta Sagrario, Miguel, Masonería española. Páginas de su historia, Madrid, Establecimiento Tipográfico, 1915.

Naranjo Orovio, Consuelo, Historia mínima de las Antillas hispanas y británicas, Ciudad de México, El Colegio de México, 2014.

Naranjo Orovio, Consuelo y Buscaglia, José F., «Race as a weapon: defending the colonial plantation order in the name of civilization, 1791-1850», Culture \& History Digital Journal, 4:2, Madrid, 2015, 1-9.

Otero González, Luis A., «La masonería autóctona y española ante la esclavitud», en Ferrer Benimeli, José A. (coord.), La masonería española, represión y exilios, Almería, CEHME, 2010, vol. I, 393-409.

Paniagua Pérez, Jesús, «Rafael María de Labra y la abolición de la esclavitud en Puerto Rico», Estudios humanísticos, 12, León, 1990, 139-156.

Paz Sánchez, Manuel de, Historia de la francmasonería en las Islas Canarias (1739-1936), Tenerife, Cabildo de Gran Canaria, 1984.

Paz Sánchez, Manuel de, Martí, España y la masonería, Tenerife, Ediciones Idea, 2008.

Pérez-Prendes y Muñoz de Arraco, José M., «La revista "El Abolicionista” (18651876) en la génesis de la abolición de la esclavitud en las Antillas españolas», Anuario de Estudios Americanos, 43, Sevilla, 1986, 215-240.

Pinto Tortosa, Antonio J., «Libertad frente a esclavismo: la Revolución Gloriosa y la cuestión abolicionista (1868-1873)», Ayer, 112, Madrid, 2018, 129-155.

Piqueras Arenas, José A., La revolución democrática (1868-1874): cuestión social, colonialismo y grupos de presión, Madrid, Ministerio de Trabajo, 1992.

Piqueras Arenas, José A. (coord.), Historia comparada de las Antillas, Madrid, Doce Calles, 2014.

Polo y Peyrolon, Manuel, Intervención de la masonería en los desastres de España, Valencia, Alufre, 1899.

Poyán Rasilla, Carmen, «Nicolás Díaz y Pérez, escritor y masón», en Ferrer Benimeli, José A. (coord.), La masonería en la España del siglo XIX, Salamanca, CEHME, 1987, vol. II, 637-647.

Pozuelo Mascareque, Belén, «Sociedad española y abolicionismo en la segunda mitad del siglo XIX», Cuadernos de Historia Contemporánea, 10, Madrid, 1988, 71-92.

Randouyer, Françoise, «Utilidad de un catálogo de masones-diputados a Cortes», en Ferrer Benimeli, José A. (coord.), La masonería en la historia de España, Zaragoza, CEHME, 1985, 55-103.

Randouyer, Françoise, «Los Comuneros de Castilla ¿Una logia revolucionaria?», en Ferrer Benimeli, José A. (coord.), Masonería, revolución y reacción, Alicante, CEHME, 1990, vol. I, 105-110. 
Randouyer, Françoise, «La logia Amor. Un prototipo de la masonería madrileña (1868-1888)», en Ferrer Benimeli, José A. (coord.), La masonería en Madrid y en España del siglo XVIII al XXI, Leganés, CEHME, 2004, vol. I, 3-35.

Rodríguez Pérez, Juan F. y Vizcarrondo Sabater, Ana, «Entre la filantropía y el humanitarismo: Julio Vizcarrondo (1829-1889) y la Sociedad Protectora de los Niños de Madrid», Foro de Educación, 10, Salamanca, 2008, 297-324.

Rojas, Rafael, «La esclavitud liberal. Liberalismo y abolicionismo en el Caribe hispano», Secuencia, Ciudad de México, 86, 2013, 29-52.

Ruibal Outes, Tomás, «La vida escénica en Pontevedra en la segunda mitad del siglo XIX», tesis doctoral dirigida por el Dr. José Romera Castillo, Universidad Nacional de Educación a Distancia, Madrid, 1997. Disponible en: https://www2.uned.es/centro-investigacion-SELITEN@T/pdf/RuibalOutes.pdf [Consultado: 14/10/2020].

Ruiz Sánchez, José L., «Francisco Salmerón y Alonso (1822-1878) y la masonería de Alhama de Almería», en Ferrer Benimeli, José A. (coord.), La masonería española, represión y exilios, Almería, CEHME, 2010, vol. I, 23-44.

Sabourin, Lise, «Jules Barbier, Cora, ou l'esclavage», Studi Francesi, 154, Turín, 2008, 212-213.

Sánchez-Gey, Juana y Paz Sánchez, Manuel, Pensamiento contemporáneo, Tenerife, Centro de la Cultura Popular Canaria, 1988.

Serván, Carmen, «Revolución de 1868 y esclavitud: atonía de la libertad», Investigaciones Históricas, época moderna y contemporánea, 37, Valladolid, 2017, 98-131.

Valín Fernández, Alberto, «Galicia y su emigración en la masonería cubana», en Ferrer Benimeli, José A. (coord.), Masonería española y América, Zaragoza, CEHME, 1993, vol. I, 513-520.

Valín Fernández, Alberto, Masonería y revolución, Tenerife, Ediciones Idea, 2008. Vaquero Iglesias, Julio A., «Masonería e independencia americana según la historiografía decimonónica española», en Ferrer Benimeli, José A. (coord.), $M a-$ sonería española y América, Zaragoza, CEHME, 1993, vol. II, 1083-1095.

Vila Vilar, Enriqueta, «Concepción Arenal, abolicionista», en Martín Casares, Aurelia y Periáñez Gómez, Rocío (eds.), Mujeres esclavas y abolicionistas en la España de los siglos XVI al XIX, Madrid, Iberoamericana-Vervuert, 2014, 235-261. 